\title{
PENGEMBANGAN MEDIA SMART BOARD PADA PEMBELAJARAN MATEMATIKA DI KELAS III SD
}

\author{
Author: \\ Romaisa Ariyanti ${ }^{1}$ \\ Elya Rosalina ${ }^{2}$ \\ Tio Gusti Satria ${ }^{3}$
}

\section{Afiliation: \\ STKIP PGRI \\ Pendidikan Guru Sekolah \\ Dasar \\ Corresponding email satriagustio@gmail.com}

Histori Naskah: Submit: 2021-10-31 Accepted: 2021-11-02 Published: 2021-12-01

\section{(c) (i) (8)}

This is an Creative Commons License This work is licensed under a Creative Commons AttributionNonCommercial 4.0 International

\begin{abstract}
Abstrak:
Penelitian ini bertujuan untuk mengetahui tingkat Kevalidan dan tingkat Kepraktisan dari media pembelajaran "Smart Board" pada pembelajaran materi matematika untuk kelas III Sekolah Dasar Negeri I Sugihwaras. Penelitian ini merupakan penelitian pengembangan dengan menggunakan model pengembangan 4-D. Berdasarkan hasil analisis penilaian yang dilakukan kepada tiga orang ahli yaitu: ahli validasi bahasa, ahli validasi materi, dan ahli validasi media menunjukkan bahwa media pembelajaran "Smart Board" pada materi matematika untuk kelas tiga SD telah memenuhi kriteria valid dengan skor rata-rata 4,25. Sedangkan untuk kepraktisan media pembelajaran "Smart Board" pada materi matematika untuk kelas tigas SD memenuhi kriteria sangat praktis dengan rata-rata 93,6, sehingga dapat disimpulkan bahwa Media pembelajaran "Smart Board" memenuhi kriteria valid, praktis dan bisa digunakan dalam pembelajaran.
\end{abstract}

Kata kunci: Matematika, media, Smart Board

\section{Pendahuluan}

Pendidikan menjadi hal yang paling utama dibutuhkan bagi manusia sebagai sarana untuk menciptakan manusia yang berhartabat. Sejalan dengan pendapat Pembelajaran adalah proses interaksi peserta didik dengan pendidik dan sumber belajar pada suatu lingkungan belajar. Pembelajaran juga membantu peserta didik dapat belajar dengan baik dan dialami sepanjang hayat seorang manusia serta dapat berlaku di manapun dan kapanpun. Menurut Suardi (2018) pembelajaran adalah proses interaksi peserta didik dengan pendidik dan sumber belajar pada suatu lingkungan belajar, pembelajaran merupakan bantuan yang diberikan pendidik agar terjadi proses perolehan ilmu dan pengetahuan, penguasaan kemahiran, dan tabiat, serta pembentukan sikap dan kepercayaan pada peserta didik. Mata pelajaran yang dapat diperoleh peserta didik melalui lingkungan seperti mata pelajaran matematika.Matematika adalah ilmu yang memiliki sifat khas seperti objek bersifat abstrak, menggunakan lambang-lambang yang tidak banyak digunakan dalam kehidupan sehari-hari, dan proses berfikir yang dibatasi dengan aturan-aturan yang ketat.

Menurut Maskuri (2019) matematika merupakan ilmu universal yang mempunyai peranan penting dalam berbagai disiplin ilmu dan mengembangkan daya pikir manusia, serta mendasari perkembangan teknologi 
modern.Selanjutnya mata pelajaran matematika perlu diberikan kepada semua peserta didik dari jenjang sekolah dasar hingga sekolah lanjutan untuk membekali peserta didik dengan kemampuan berfikir logis, analitis, sistematis, kritis dan kreatif serta dapat menyelesaikan masalah yang dihadapinya dalam kehidupan sehari-hari. Berdasarkan hasil observasi dan wawancara yang dilakukan pada tanggal I Desember 2020 oleh penulis dengan guru kelas III di SD Negeri I Sugiwaras, penulis menemukan masalah pada peserta didik ketika pembelajaran sulit untuk menguasai materi karena motivasi belajar yang rendah, motivasi yang rendah terhadap mata pelajaran matematikan karena guru tidak menggunakan media pembelajaran pada saat proses pembelajaran berlangsung.Oleh karena itu guru bisa mengaplikasikan media Smart Board untuk proses pembelajaran disekolah. Menurut Levie dan Lentz dalam (Nurdyansyah 2019:58) fungsi media pembelajaran sebagai berikut: 1) Fungsi atensi, 2) Fungsi afektif, 3) Fungsi kognitif, dan terakhir, 4) Fungsi kompensatoris.

Berdasarkan hasil penelitian Arvianto dan Widayati (2020) dengan judul pengembangan media Smart Board Mathematics pada Mata Pelajaran Matematika Materi KPK dan FPB di kelas V bahwa media pembelajaran Smart Board valid dan layak digunakan dalam proses pembelajaran. Berdasarkan data penilaian yang diperoleh terhadap produk media Smart Board Mathematics sebagai berikut: validasi guru pada uji coba kelompok kecil dan uji coba kelompok besar mendapat skor 95 masuk kriteria kelayakan sangat layak, sedangkan uji coba pada kelompok kecil mendapatkan skor 43,16 masuk kriteria kelayakan sangat layak dan uji coba pada kelompok besar mendapat skor 44,709 masuk kriteria kelayakan sangat layak. Berdasarkan data yang diperoleh dengan demikian media Smart Board Mathematics yang dikembangkan di kelas V pada materi KPK dan FPB layak digunakan dalam proses pembelajaran. Berdasarkan permasalahan tersebut maka penulis tertarik untuk mengembangkan media pembelajaran yang berjudul: "Pengembangan Media Smart Board pada Pembelajaran di kelas III SD".

\section{Studi Literatur}

Media pembelajaran mencakup manusia, materi atau kajian yang membangun suatu kondisi yang membuat peserta didik mampu memperoleh pengetahuan, keterampilan atau sikap (Tio Gusti Satria, 2020). Dalam pemilihan media harus memperhatikan kriteria-kriteria sebagai berikut : pembelajaran Kemampuan mengakomondasi penyajian stimulus yang tepat (visual dan audio), mampu mengakomondasikan peserta didik yang tepat (tertulis, audio dan kegiatan fisik), kemampuan akomondasi umpan balik, pemilihan media utama dan sekunder untuk penyajian informasi dan stimulus untuk latihan dan tes menggunakan media yang sama selanjutnya tingkat kesenangan (preferensi lembaga, guru dan pelajar) dan keefektivan biaya. pemilihan media pembelajaran perlu memperhatikan ketepatan memilih media yang akan digunakan dalam proses pembelajaran. Apabila tidak tepat memilih, tentu media tidak dapat menujang kelancaran proses pembelajaran Arsyad (2016). Beberapa kriteria umum yang perlu diperhatikan dalam memilih media yang akan digunakan sebagai berikut: 1) kesesuain dengan tujuan (instructional goals) perlu dikaji tujuan pembelajaran apa yang ingin dicapai dalam suatu kegiatan instruksional khusus (TIK), 2) Kesesuain dengan materi pembelajaran, bahan dan materi yang akan diajarkan, 3) Kesusuaian dengan karakteristik pembelajaran atau peserta didik. Dalam hal ini media harus familiar dengan karakteristik peserta didik, 4) Kesesuain dengan teori, pemilihan media harus sesuai dengan materi, 5) Kesesuaian dengan gaya belajar siswa, kriteria ini sesuai dengan psikologi peserta didik (Amka, 2018) Media pembelajaran sangat penting untuk menyampaikan tujuan pembelajaran dengan tepat dan tidak monoton. Smart board merupakan suatu brend/merek yang sangat luas oleh masyarakat internasional. Di Indonesia sendiri sudah banyak masyarakat yang sudah mengenal kata smart board, terlebih lagi di sektor pendidikan menurut liputan6 (2021). Smart Board adalah salah satu media yang awalnya untuk media matematika, tetapi bila dikembangkan dengan 
Edu Cendikia: Jurnal Ilmiah Kependidikan

Volume: 1 | Nomor 3 | Desember 2021 | E-ISSN: 2798-365X | DOI: 10.47709/educendikia.v1i3.1147

kreativitas yang bertanggung jawab, maka dapat difungsikan untuk pembelajaran lain menurut (Sanjaya, 2015).

\section{Metode Penelitian}

Penelitian ini menggunakan pendekatan kuantitatif dengan model pengembangan 4-D. Model pengembangan 4-D ini memiliki empat tahapan pengembangan yaitu: Define, Design, Develop, dan Desseminate atau diadaptasikan menjadi model 4-P yaitu pendefinisian, perancangan, pengembangan, dan penyebaran (Muhajir 2015).Metode yang dilakukan observasi. Pengumpulan data menggunakan angket respon guru dan peserta didik. Angket peserta didik adalah tehnik atau cara pengumpulan data secara tidak langsung (penulis tidak langsung bertanya-jawab dengan responden) dengan 8 pertanyaan. Angket ini berisi beberapa pernyataan yang kemudian akan dijawab dengan responden. Dengan kata lain angket adalah daftar pertanyaan yang akan diberikan kepada orang lain yang bersedia memberikan respon sesuai permintaan pengguna sedangkan angket respon guru.

Angket validasi bertujuan untuk mengetahui kevalidan media pembelajaran Smart Board. Instrumen yang digunakan untuk menganalisis kevalidan adalah angket penilaian yang diperuntukan ahli materi, ahli bahasa dan ahli media. Menghitung Skor Rata-rata Menghitung skor total rata-rata seluruh aspek yang dinilai dengan rumus sebagai berikut :

$$
\bar{x}=\frac{\sum x}{n}
$$

Sedangkan angket respon peserta didik bertujuan untuk mengetahui tingkat kepraktisan dari media pembelajran Smart Board. Angket digunakan untuk pengumpulan data membuat daftar pertanyaan untuk mengetahui respon guru dan peserta didik mengenai media pembelajaran dan diberikan kepada para ahli yaitu: ahli materi, ahli bahasa dan ahli media Angket respon guru Angket dengan menggunakan 7 pertanyaan (Sugiyono, 2020).

Instrumen yang digunakan untuk menganalisis kevalidan adalah angket penilaian yang diperuntukan angket respon guru dan peserta didik. Menghitung Skor Rata-rata Menghitung skor total rata-rata seluruh aspek yang dinilai dengan rumus sebagai berikut :

$$
x=\frac{\text { Jumlah skor yang di peroleh }}{\text { jumlah skor total }} x 100 \%
$$

Dalam menganlisis instrumen penelitian, penelitian ini menggunakan uji validitas terlebih dahulu, untuk mengetahui valid dan praktis tidaknya suatu instrumen penelitian. Jika instrumen penelitian menunjukan hasil yang benar maka dikatakan valid dan praktis, tetapi jika instrumen penelitian menunjukan hasil di bawah rata-rata maka dikatakan tidak valid dan praktis. 
Edu Cendikia: Jurnal Ilmiah Kependidikan

Volume: 1 | Nomor 3 | Desember 2021 | E-ISSN: 2798-365X | DOI: 10.47709/educendikia.vli3.1147

\section{Hasil}

Setelah penelitian digunakan dengan menyebarkan angket respon peserta didik dengan 8 pertanyaan kepada 6 responden, kemudian diteliti satu persatu dan diberikan penilaian sesuai dengan jawaban responden. Skor rata-rata yang diperoleh 93,6. Sedangkan angket respon guru dengan 7 pertanyaan mendapatkan skor ratarata 4. Nilai ini diperoleh dari pengisian kuesioner pnelitian yang memberikan informsi sebagai berikut: 5 (sangat baik), 4 (baik), 3 (cukup baik), 2 (kurang baik) dan 1 (tidak baik).

Tabel 1. Hasil perhitungan angket peserta didik

\section{A. Respon Pesrta Didik}

\begin{tabular}{|c|c|c|c|c|c|c|c|c|c|c|c|}
\hline \multirow[b]{2}{*}{ Responden } & \multicolumn{8}{|c|}{ Tem } & \multirow{2}{*}{$\begin{array}{c}\text { Skor } \\
\text { Maksimum }\end{array}$} & \multirow{2}{*}{$\begin{array}{l}\text { Skor yang } \\
\text { diperoleh }\end{array}$} & \multirow{2}{*}{$\begin{array}{c}\text { Skor } \\
\text { Rata- } \\
\text { rata }\end{array}$} \\
\hline & 1 & 2 & 3 & 4 & 5 & 6 & 7 & 8 & & & \\
\hline CK & 1 & 1 & 1 & 0 & 1 & 1 & 0 & 1 & 8 & 6 & 75 \\
\hline $\mathrm{K}$ & 1 & 1 & 1 & 1 & 1 & 1 & 1 & 1 & 8 & 8 & 100 \\
\hline WT & 1 & 1 & 1 & 1 & 1 & 1 & 1 & 1 & 8 & 8 & 100 \\
\hline YA & 1 & 1 & 1 & 1 & 1 & 1 & 1 & 1 & 8 & 8 & 100 \\
\hline ADP & 1 & 1 & 0 & 1 & 1 & 1 & 1 & 1 & 8 & 7 & 87 \\
\hline SA & 1 & 1 & 1 & 1 & 1 & 1 & 1 & 1 & 8 & 8 & 100 \\
\hline \multicolumn{11}{|c|}{ Jumlah Keseluruhan } & 562 \\
\hline
\end{tabular}

Cara menghitung rata-rata menggunakan rumus dapat diperoleh nilai rata-rata yang diberi oleh angket respon peserta didik yaitu :
a. Siswa $1(\mathrm{CK})$

$$
x=\frac{6}{8} x 100=75
$$

Jadi rata-rata respon peserta didik yang didapat 75 yang dikategorikan praktis dan dapat digunakan.

b. Siswa $2(\mathrm{~K})$

$$
x-\frac{8}{8} x 100
$$

Jadi rata-rata respon peserta didik yang didapat 100 yang dikategorikan sangat praktis dan dapat digunakan 
c. Siswa $3($ WT)

$$
x-\frac{8}{8} x 100=100
$$

Jadi rata-rata respon peserta didik yang didapat 100 yang dikategorikan sangat praktis dan dapat digunakan

d. Siswa $4(\mathrm{YA})$

$$
x-\frac{8}{8} x 100=100
$$

Jadi rata-rata respon peserta didik yang didapat 100 yang dikategorikan sangat praktis dan dapat digunakan.

e. Siswa 5 (ADP)

$$
x-\frac{7}{8} x 100=87
$$

Jadi rata-rata respon peserta didik yang didapat 87 yang dikategorikan sangat praktis dan dapat digunakan.

f. Siswa $6(\mathrm{SA})$

$$
x-\frac{8}{8} x 100=100
$$

Jadi rata-rata respon peserta didik yang didapat 100 yang dikategorikan sangat praktis dan dapat digunakan.

\section{Rekapulasi nilai peserta didik}

$\mathrm{x}: \frac{\text { Jumlah skor yang di peroleh }}{\text { jumlah skor total }}$

Maka diperoleh

$$
\mathrm{x}: \frac{562}{6}=93,6
$$

Dapat kita simpulkan bahwa hasil akhir nilai respom peserta didik adalah 93,6 yang dikategorikan sangat praktis digunakan. 
Edu Cendikia: Jurnal Ilmiah Kependidikan

Volume: 1 | Nomor 3 | Desember 2021 | E-ISSN: 2798-365X | DOI: 10.47709/educendikia.vli3.1147

Tabel 2. Hasil perhitungan angket respon guru

\section{Respon Guru}

\begin{tabular}{|l|l|l|l|l|l|l|}
\hline No & Pertanyaan & 1 & 2 & 3 & 4 & 5 \\
\hline 1 & Kepraktisan media & & & & & \\
\hline 2 & Keselasaran warna & & & & \\
\hline 3 & Kegunaan media & & & & \\
\hline 4 & Berguna dalam proses pembelajaran & & & & \\
\hline 5 & Menggunakan contoh soal yang sesuai dengan materi & & & & \\
\hline 6 & Mendorong peserta didik untuk aktif & & & & \\
\hline 7 & Menciptakan kemampuan bertanya & & & & & \\
\hline
\end{tabular}

Cara menghitung hasil respon guru :

Cara menghitung rata-rata menggunakan rumus :

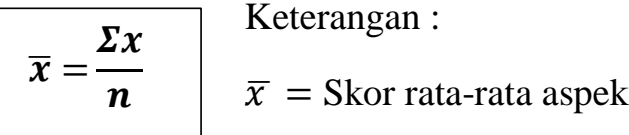

$$
\begin{aligned}
& \Sigma \chi=\text { Jumlah skor seluruh aspek } \\
& n \text { = Banyak nya butir pertanyaan (6) }
\end{aligned}
$$

Dari rumus tersebut dapat diperoleh nilai rata-rata yang diberi ahli bahasa yaitu :

$\bar{x}-\frac{24}{6}-4$ jadi rata-rata yang diperoleh dari ahli bahasa yaitu 4 yang dikategorikan baik, dapat diartikan valid digunakan.

\section{Pembahasan}

Dari hasil pengujian yang dilakukan, didapatkan bahwa penilain pengembangan media oleh ahli media diperoleh rata-rata 4,63 atau sangat valid. Sedangkan untuk ahli Bahasa diperoleh nilai rata-rata 4 yang berarti valid. Hal ini layak untuk uji cobakan tanpa revisi. hal ini layak untuk di uji cobakan tanpa revisi dan untuk ahli materi diperoleh nilai rata-rata 4 yang berarti valid dari segi materi. Hal ini layak untuk uji cobakan dengan revisi sesuai saran. Berdasarkan data pengisian angket oleh ketiga validator menunjukan bahwa dalam pengembangan media yang telah diperbaiki berdasarkan perhitungan data pengisian angket dengan skor rata-rata 4,25 dengan kriteria "valid" dapat diartikan bahwa pengembangan Media Smart Board layak digunakan. 
Pelaksanaan uji kepraktisan kelompok kecil yang terdiri 6 orang peserta didik dengan kemampuan tinggi, sedang dan rendah. Berdasarkan hasil angket kelompok kecil yang diperoleh, dapat disimpulkan bahwa respon peserta didik terhadap media Smart Board materi jenis bilangan cacah adalah sangat praktis dengan skor rata-rata 93,6. (sangat praktis).

\section{Kesimpulan}

Proses pembelajaran menggunakan media pembelajaran dapat membantu peserta didik untuk memahami materi. Berdasarkan hasil angket respon peserta didik dan angket respon guru sangat valid dan valid, jadi media smart board dapat digunakan dalam proses pembelajaran dan membantu peserta didik untuk memahami materi. Bagi penulis selanjutnya untuk melaksanaan penelitian bukan hanya sampai tahap 3D melainkan sampai dengan 4D yakni desiminate sehingga akan didapatkan sebuah penegembangan media pembelajran yang lebih valid dan praktis digunakan pada jenjang sekolah dasar.

\section{Referensi}

Amka. 2018. Media Pembelajaran Inklusi. Sidorejo: Nizamia Learning Center.

Arsyad Azhar. 2010. Media Pembelajaran.Jakarta; Rajawali Prees

Arvianto, Sigit., dan Widayati. (2020). Pengembangan Media Smart Board Mathematics Pada Mata Pelajaran Matematika Materi KPK dan FPB di Kelas V. UMM Institutional Repository. Volume 37 No.1.

Liputan6.Com.https:/m.liputan6.com/tekno/read/2228966/papan-tulis pintar-smart-board-tunjang-duniapendidikan-indonesia.

Mashuri, Sufri. (2019). Media Pembelajaran Matematika. Yogyakarta: CV Budin Utama.

Muhajir, Al, Muhammad. (2015). Pengembangan Penuntun praktikum bioteknologi kelas XII IPA SMA NEGERI Kab. Jeneponto Jurnal Biotek. Volume 3 No. 1.

Nurdyansyah. (2019). Media Pembelajaran Inovatif. Universitas Muhammadiyah Sidoarjo: UMSIDA Press

Sanjaya. (2015). Kurikulum dan Pembelajaran (Teori dan Praktik Perkembangan Kurikulum Tingkat Satuan Pendidikan). Jakarta: Prenadamedia Group

Sugiyono, 2020. Metode Penelitian Kualitatif. Bandung: Alfabeta.

Suhardi, Moh. (2018). Belajar dan Pembelajaran. Yogyakarta: Deepublish.

Tio Gusti Satria, A. S. E. (2020). Pengembangan Etnosains Multimedia Learning Untuk Meningkatkan Kognitif Skill Siswa SD di Kota Lubuklinggau. Basicedu, 4(1), 13-21. https://doi.org/https://doi.org/10.31004/basicedu.v4i1.382 